\title{
Poesia e história em Walter Benjamin: do poetificado ao poema como mônada
}

Rafael Zacca Fernandes

Professor do Departamento De FIlosofia da PUC-Rio

\section{Um verso estranho de Baudelaire}

No final da década de 1920, Walter Benjamin havia se aproximado das teses do materialismo histórico. E, ao longo da década de 1930, o filósofo viu a ascensão do nazismo e do fascismo ao poder, e, com eles, a chegada da Segunda Guerra Mundial (judeu e comunista, precisou se exilar na França no período imediatamente anterior à sua fuga malograda pelos Pirineus e ao suicídio). Não deixa de ser curioso que, na eclosão da guerra, Benjamin se dedique a escrever um livro sobre o poeta francês Charles Baudelaire.

Se ao materialismo histórico cabia pensar e transformar as questóes materiais que submetem as classes oprimidas, por que Benjamin escreve um livro de crítica de poesia? Se ao materialismo histórico, na década de 1930, cabia enfrentar o imperialismo, o colonialismo e nazifascismo, em que sentido uma obra como essa seria desejável? Por que não adiar o plano de investigação e escrita para outra década, e se dedicar à pesquisa histórica, ou econômica, ou política, ou das relaçôes de poder? Por que não investigar um poeta revolucionário (no sentido que essa palavra carrega quando nos referimos a alguém que se filia explicitamente a um 
projeto de sociedade socialista, comunista etc.)? Uma vez que Baudelaire não era exatamente esse "revolucionário" - apesar de ser alguém que certamente amava a revolta -. Tpor que se debruçar sobre a sua poesia e sobre a Paris do século XIX? Como, exatamente, isso estaria à altura do combate mais urgente da época?

A exigência de se defrontar também no âmbito da cultura, na prática e no campo das ideias, com os regimes autoritários e eugênicos de sua época, sob o risco de que seu próprio corpo e vida desaparecessem, já havia sido colocada por textos de Walter Benjamin que remontam aos primeiros anos da ascensão de Hitler, na década de 1930. Como em "O autor como produtor", quando foi conferencista no Instituto para o Estudo do Fascismo, cujas ideias centrais exigiam um real engajamento da "inteligência" com o proletariado na sua luta contra o capitalismo a partir de uma refuncionalização da escrita $\left.\right|^{2} \mathrm{Ou}$ como, mais tarde, em "A obra de arte na era de sua reprodutibilidade técnica", quando convocou artistas e críticos a uma "politização da arte" contra uma "estetização da política" promovida pelo fascismo. 3 Para não falar nas "correçóes” que aplicou ao falso engajamento de intelectuais e artistas pequeno-burgueses, como o poeta Erich Kästner, que se contentava com uma solidariedade ideológica com o proletariado,

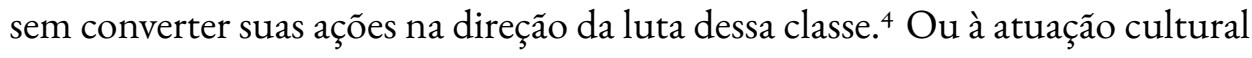
da socialdemocracia alemã nos anos que precederam a vitória de Hitler - para Benjamin, a mera popularização do saber promovida pelos socialistas democratas, sem a transformação prévia desse mesmo saber em um sentido revolucionário, seria inofensiva politicamente.5

' Para Benjamin, a máxima de Flaubert - "de toda política só entendo uma coisa: a revolta” - poderia ter sido dita por Baudelaire. "O que Baudelaire assim registra poder-se-ia denominar a metafísica do provocador.” BENJAMIN, Walter. Charles Baudelaire, um lírico no ange do capitalismo. Obras escolhidas. V. 3. Trad. José Carlos Martins Barbosa; Hemerson Alves Batista. São Paulo: Brasiliense, 1989, p. II.

${ }^{2}$ BENJAMIN, Walter. Magia e técnica, arte e politica. Obras escolhidas. V. I. Trad. Sergio Paulo Rouanet. São Paulo: Brasiliense, 1987, p. 136.

${ }^{3}$ Ibid., p. 196.

${ }^{4}$ Ibid., pp. 73-78.

5 “Ao lema 'Trabalho e Cultura' (...) a social-democracia opôs outro que dizia 'Saber é poder'. Mas não se apercebeu do seu duplo sentido. Achava que o mesmo saber que consolidou a dominação do proletariado pela burguesia levaria também aquele a libertar-se dessa dominação. 
Em 1940, essas exigências se conjugariam com mais uma, não menos elementar: a da reformulação de um conceito de história à altura da tarefa revolucionária do materialismo histórico. Em seus fragmentos "Sobre o conceito de história", Benjamin argumentava em favor de uma concepção de tempo histórico que pudesse se contrapor àquela pressuposta na ideologia do progresso (que concebia a história como uma escalada rumo à felicidade coletiva nos moldes do desenvolvimento da civilização ocidental). ${ }^{6}$ De seu ponto de vista, essa mesma ideologia servia de fundamento para que se considerassem os regimes fascistas como uma espécie de ruptura histórica com a modernidade - e não como uma possibilidade histórica da própria civilização moderna.

Ora, para Benjamin, e isso fica claro no fragmento número oito, a história da humanidade é a história do Estado de Exceção.7 A crítica ao conceito de progresso se aliava a uma tentativa de acompanhar a empresa do homo sapiens sobre a Terra, sob a narrativa de que a sua relação tanto com a natureza quanto com outros seres humanos se daria pela dominação. $\left.\right|^{8}$ Tal dominação entraria em contradição com as aspirações da civilização por justiça e liberdade: de tempos em tempos, o monopólio da violência seria entregue a mãos tirânicas que poderiam garantir a manutenção das relações de poder e produção vigentes. Esse seria o mecanismo de reprodução das relações entre dominadores e dominados de todas as eras. Assim, assegurar-se-ia a continuidade, se não dos projetos das classes dominantes, pelo menos da estrutura de dominação fundamental humana.

Qual é a relação, então, entre a investigação crítica de um poeta lírico e a tarefa do materialismo histórico de Walter Benjamin?

$\mathrm{Na}$ verdade, um saber sem acesso à praxis e que nada podia ensinar ao proletariado sobre a sua situação de classe era inofensivo para os seus opressores. Isso se aplica especialmente ao saber das 'ciências do espírito'.” BENJAMIN, Walter. "Eduard Fuchs, colecionador e historiador.” In: $O$ anjo da história. Trad. João Barrento. Belo Horizonte: Autêntica Editora, 20I2, p. I33.

${ }^{6}$ BENJAMIN, Walter. 1987, p. 222-232.

7 “A tradição dos oprimidos nos ensina que o 'estado de exceção’ em que vivemos é na verdade a regra geral. Precisamos construir um conceito de história que corresponda a essa verdade. Nesse momento, perceberemos que nossa tarefa é originar um verdadeiro estado de exceção; com isso, nossa posição ficará mais forte na luta contra o fascismo.” Ibid., p. 226.

${ }^{8}$ Cf. o décimo primeiro fragmento. Ibid., p. 227-228. 
Entre os textos que integrariam o livro sobre Charles Baudelaire, restou um ensaio de Benjamin que se dedica a compreender "Alguns temas em Baudelaire". Trata-se da subseção de um segundo capítulo (o primeiro e o terceiro jamais foram escritos) da obra inconclusa destinada a apresentar uma imagem do poeta francês e do estatuto lírico de sua poesia em uma situação histórica antilírica por excelência: o auge do capitalismo.

Ao trabalhar "Alguns temas em Baudelaire" em sala de aula, costumo perguntar aos meus alunos: sobre o que é esse ensaio? Fazemos uma lista, com a qual geralmente concluímos que Benjamin trata de alguns dos seguintes itens: a pobreza de experiência das geraçôes que viveram no século XIX; o recalcamento dessa situação em algumas dessas gerações; as origens do nazifascismo na Europa; a atrofia da aura; a modificação no estatuto do Belo nas obras de arte; a invenção do romance policial; o surgimento das medidas de controle social na França pósrevolucionária; o advento das massas nos grandes centros urbanos; a mudança da percepção na modernidade e a transformação da memória; o pouco prestígio de As flores do mal quando publicado pela primeira vez e a situação de sua fama ao longo das décadas seguintes.

No entanto, é possível afirmar o seguinte: todo o ensaio se destina a compreender uma única questão. Uma aparente contradição em um verso de Baudelaire, em que o poeta qualifica e denuncia o seu leitor como hipócrita, ao mesmo tempo em que se identifica com ele como seu semelhante. "-Hypocrite lecteur, - mon semblable, - mon frère!"

O verso figura no poema "Ao leitor", 9 que abre As flores do mal e descreve uma humanidade corrompida. O poeta se inclui nessa humanidade. Dar a imagem de seu próprio tempo e do gênero humano que o vive não apenas como decaídos, mas também degenerados, é uma das tarefas de suas flores. Entregue ao pecado, ao vício e a "amáveis remorsos" (aimables remords, conforme a primeira estrofe do poema "Ao leitor"), sob o comando de Satã Trimegisto (terceira estrofe), essa humanidade, que tem a cabeça povoada de demônios (sexta estrofe), parece ostentar, para o poeta, uma alma apaixonada pelo mal (como também pela violação, pelo veneno, pelo punhal e pelo fogo, conforme a sétima estrofe).

9 BAUDELAIRE, Charles. As flores do mal. Trad. Ivan Junqueira. In: Poesia e prosa. Volume único. Rio de Janeiro: Nova Aguilar, 1995, p. I03-IO4. 
No entanto, nenhum dos vícios ou dos males que ocupam a alma e trabalham no corpo humano se iguala ao maior deles, que com um único "bocejo imenso engoliria o mundo":

$$
\begin{aligned}
& \text { É o Tédio! [l'Ennui] - O olhar esquivo à mínima } \\
& \text { emoção, } \\
& \text { Com patíbulos sonha, ao cachimbo agarrado. } \\
& \text { Tu conheces, leitor, o monstro delicado } \\
& \text { - Hipócrita leitor, - meu igual [ou semelbante], - } \\
& \text { meu irmão! }
\end{aligned}
$$

O tédio assume, no poema, a forma de uma entidade (l'Ennui / o Tédio) e é alçado à categoria de maior e mais imundo dos vícios humanos. Não é obra somente do poeta. Nos anos I840, o tédio teria sido tomado como uma espécie de epidemia, um mal do séculomPara Benjamin, como para observadores do próprio século XIX, o fenômeno estava associado, pelo menos em Paris, à influência que o tempo atmosférico, acinzentado depois do inchaço da capital, tinha sobre a sensação temporal cronológica das pessoas. Esse efeito de névoa, em que se misturam fumaça industrial e bruma, receberia o nome inglês de spleen - um sentimento indeterminável, entre o tédio e a melancolia. Em um dos poemas de As flores do mal que levam esse nome, "Spleen", Baudelaire oferece a imagem da indistinção entre tempo atmosférico e tempo vazio do sujeito na forma de um cortejo fúnebre:

Io Ibid., p. Io4 No original: "C'est l'Ennui! - l'oeil chargé / 'un pleur involontaire, / Il rêve d'échafauds en fumant son houka./ Tu le connais, lecteur, ce monstre délicat, / - Hypocrite lecteur, - mon semblable, - mon frère!”

${ }^{\text {II }}$ E, segundo Benjamin, Lamartine fora o primeiro a exprimir esse mal. Para ilustrá-lo, Benjamin cita a famosa anedota sobre o comediante Deburau: "Certa feita, um grande neurologista foi procurado por um paciente que o visitava pela primeira vez. O paciente queixou-se do mal do século - a falta de vontade de viver, as profundas oscilaçóes de humor, o tédio. 'Nada de grave', disse o médico após minucioso exame. 'O senhor precisa apenas repousar, fazer algo para se distrair. Uma noite dessas vá assistir a Deburau e o senhor logo verá a vida com outros olhos.' 'Ah, caro senhor', respondeu o paciente, 'eu sou Deburau'.” BENJAMIN, Walter. Passagens. Trad. Irene Aron e Cleonice Paes Barreto Mourão. Belo Horizonte: Editora UFMG, 2009, p. 48-49. 
Quando o céu plúmbeo e baixo pesa como tampa

Sobre o espírito exposto aos tédios e aos açoites,

E, ungindo toda a curva do horizonte, estampa

Um dia mais escuro e triste do que as noites;

(...)

- Sem música ou tambor, desfila lentamente

Em minha alma uma esguia e fúnebre carreta;

Chora a Esperança, e a Angústia, atroz e prepotente,

Enterra-me no crânio uma bandeira preta $\left.\right|^{\text {I2 }}$

No entanto, em "Sobre alguns motivos na obra de Baudelaire", ao comentar o último verso de "Ao leitor" (“- Hipócrita leitor, - meu igual, - meu irmão!"), Benjamin não se demora sobre o tema do tédio, pelo menos não à primeira vista. Veremos, porém, como o tédio é uma espécie de sintoma de algo que se passa no inconsciente coletivo a partir de transformações sociais traumáticas que transformam a percepção humana - essa sim, objeto de extenso interesse do ensaio.

Benjamin sublinha que o poema "Ao leitor" qualifica o público como "ingrato”. Ingrato diante da poesia lírica, que exige concentração, interesse, atenção. O leitor a que se dirige As flores do mal é absorto, desinteressado, distraído. Em uma palavra, essas pessoas "preferem os prazeres dos sentidos", uma vez que se en-

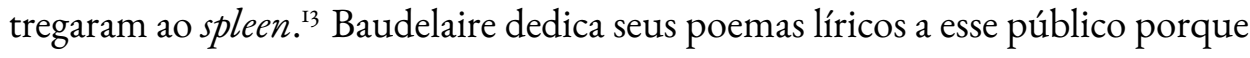
se identifica com ele. Porque passou pelas mesmas transformações traumáticas.

São transformações na estrutura de sua experiência, ocasionadas pela metamorfose da vida moderna europeia (e que não tardaria a integrar o projeto colonial na África, na Ásia e nas Américas). O encurtamento das distâncias e do tempo (com as ferrovias, o controle do tempo pelos relógios mecânicos, novos

${ }^{12}$ Tradução de Ivan Junqueira. BAUDELAIRE, Charles. Op. cit., p. I62-163. No original: "Quand le ciel bas et lourd pèse comme un couvercle / Sur l'esprit gémissant en proie aux longs ennuis, / Et que de l'horizon embrassant tout le cercle / Il nous verse un jour noir plus triste que les nuits; // (...) - Et de longs corbillards, sans tambours ni musique, / Défilent lentement dans mon âme; / l'Espoir, Vaincu, pleure, et l'Angoisse atroce, despotique, / Sur mon crâne incliné plante son drapeau noir."

'3 BENJAMIN, Walter, 1989, p. I03. 
meios comunicacionais), a força destradicionalizante do capitalismo, a nova vida plena de acidentes e perigos da metrópole, tudo isso e muito mais comporta uma nova maneira de habitar a Terra, e, portanto, exige um novo aparelho sensorial ${ }^{\sqrt{14}}$

O que, no entanto, torna o verso verdadeiramente estranho é que ele se dirige a esse público "ingrato" (diante da poesia lírica) como um "igual” (ao poeta lírico), ao mesmo tempo em que o qualifica como "hipócrita”. A tradução de Ivan Junqueira, que utilizamos até aqui, é insuficiente para a nossa análise. Vejamos o verso em francês: Baudelaire não diz "mon égal", meu igual, mas "mon semblable", meu semelhante. A voz de "Ao leitor" não se vê em relação de igualdade com esse leitor, mas em relação de semelhança, o que implica, portanto, algum nível de diferença. Onde se localiza essa diferença? A chave está no adjetivo com que qualifica o leitor, mas não a si mesmo: hipócrita leitor.

Entre as tarefas a que se destinam a obra de Baudelaire, conta-se esta: escancarar, nas formas do mal (do satanismo, do vício, da putrefação, da melancolia, da vida considerada, naquele momento, mesquinha, a das ruas, dos trapos, da boemia e da vadiagem), a nova configuração existencial da grande cidade capitalista que fora, nos seus anos iniciais, imediatamente recalcada. É justamente aí que se diferencia do seu leitor: Baudelaire atravessou as mesmas vivências (Erlebnis é o termo que Benjamin usa para qualificar essa vida do indivíduo na modernidade) do choque que traumatizou os seus leitores. Mas, ao contrário destes, o poeta não tentou fugir desse choque, e sim confrontá-lo. Não tentou recalcá-lo, mas vivê-lo - e, por fim, expressá-lo.

A tarefa de Benjamin era a de descrever a poesia de Baudelaire em função dessas transformações. No entanto, não o fez a partir de um "fora” da obra de Baudelaire - não seguiu nenhum imperativo de prioridade do social sobre o poético, que resultaria, em última instância, na investigação da sociedade primeiro para depois realizar a exposição crítica. Pelo contrário, colocou a possibilidade de existência

${ }^{14}$ Cf. BUCK-MORSS, SUSAN. "Estética e anestética: o ensaio sobre a obra de arte de Walter Benjamin”. Trad. Rafael Lopes Azize. Travessia: revista de literatura, n. 33. Florianópolis: EdUFSC, ago.-dez. 1996, p. II-4I. E também CRARY, Jonathan. Técnicas do observador. Trad. Verrah Chamma. Rio de Janeiro: Contraponto, 2012. 
do poema condicionada a uma convulsão social que não é estranha aos versos, mas que os fundamenta. Apenas a leitura minuciosa, em escala micrológica, fornece essas chaves de interpretação. Nesse sentido, Benjamin não vê a obra de Baudelaire de fora; mergulha nela.

Ao fazê-lo, no entanto, ao tentar compreender o verso estranho de Baudelaire, Benjamin termina por desdobrar tudo aquilo que lhe é inerente, realizando, de fato, aquilo que meus alunos percebem como sendo os temas do ensaio: uma teoria da pobreza de experiência das gerações que viveram no século XIX; uma descrição do recalcamento dessa situação em algumas dessas gerações; uma recapitulação das origens do nazifascismo na Europa; uma investigação da atrofia da aura; uma consideração acerca da modificação no estatuto do Belo nas obras de arte; uma explicação da invenção do romance policial; uma história do surgimento das medidas de controle social na França pós-revolucionária; uma explanação das consequências do advento das massas nos grandes centros urbanos; uma análise da mudança da percepção na modernidade e da transformação da memória; uma teoria explicativa do pouco prestígio de As flores do mal quando publicado pela primeira vez e da situação de sua fama ao longo das décadas seguintes.

\section{Monadologia}

O vertiginoso nesse método é que todo o universo histórico convocado se dedique a esclarecer um paradoxo num único verso de Baudelaire, entre a semelhança com o leitor e a acusação de uma atitude com a qual o poeta não se identifica. Essa metodologia, destinada a iluminar um detalhe, um ponto singular numa obra, e que, ao fazê-lo, descortina uma imagem mais ampla da época, é derivada da concepção das mônadas. Trata-se de uma monadologia do poema. $\mathrm{O}$ poema, em Walter Benjamin, é uma mônada.

A menor partícula existente é construída à semelhança do mundo. Em qualquer detalhe da existência, é possível encontrar vestígios de tudo aquilo que se passou e que se passa, e de tudo aquilo que se passará. E ainda, é possível ver em qualquer partícula tudo aquilo que poderia ter se passado. A ideia é de Leibniz nasce no século XVII, com a concepção de uma substância simples semelhante ao Universo, no seu Discurso de metafísica, e ganha o nome de mônada na sua Monadologia no século XVIII. 
Leibniz foi o inventor do cálculo infinitesimal; isso explica a configuração infinitesimal que apresenta da realidade. E, enquanto teólogo, formulou a possibilidade de conhecimento do Universo na substância simples, reservada, em sua realização, aos olhos de Deus. No Discurso de metafísica, Leibniz toma o exemplo de Alexandre, o Grande, fabulando o momento anterior às suas conquistas como imperador, e diz:

Quando se considera bem a conexão das coisas, pode dizer-se que, na alma de Alexandre, há, desde sempre, restos de tudo o que lhe aconteceu e sinais de tudo o que lhe acontecerá, e até mesmo vestígios de tudo o que se passa no universo, embora só a Deus caiba reconhecê-los a todos. .15 $^{15}$

É o que se passa também com as mônadas. Elas exprimem em si a imagem do mundo. Nesse sentido, cada substância simples testemunha e multiplica a boa obra de Deus, através de sua representação. É o que tem em mente Leibniz ao afirmar, na Monadologia, que "cada substância simples tem relaçôes que exprimem todas as outras", fazendo de cada mônada, portanto, "um espelho vivo e perpétuo do universo" ${ }^{16}$ A mônada é o lugar em que o singular e o universal coincidem. Desse modo, também configura um ponto de encontro entre unidade e multiplicidade.

Benjamin era fascinado por pequenos objetos, detalhes e pormenores. Uma espécie de páthos materialista que se apresentava com feição metafísica - manifestada na sua capacidade de encontrar semelhanças e parentescos lá onde a mera observação do fenômeno não os pode captar. Essas duas posições - amor ao detalhe e capacidade de identificação de semelhanças insuspeitas - foram bem formuladas por duas pessoas bastante próximas a Benjamin. É Hannah Arendt quem comenta a sua "paixão pelas coisas pequenas, até minúsculas”, e lembra que "Scholem conta da sua ambição de colocar cem linhas escritas na página comum de um caderno de notas, e da sua admiração por dois grãos de trigo na

is LEIBNIZ, Gottfried Wilhelm. A Monadologia; Discurso de metafísica e outros textos. Trad. Carlos Lopes de Mattos. São Paulo: Abril Cultural, 1979. p. 25-26.

${ }^{16}$ Ibid., p. Iı. 
seção judaica do Museu de Cluny, 'onde uma alma irmã inscrevera na íntegra o Shema Israel". Ela ressalta que, para Benjamin, "a dimensão de um objeto era inversamente proporcional à sua significação", ${ }^{77} \mathrm{E}$ Theodor W. Adorno menciona como, em tudo o que dizia ou escrevia, o pensamento do amigo assumia "as promessas dos contos de fadas e dos livros infantis, ao invés de recusá-las e repeli-las em nome de uma infame maturidade" ${ }^{18}$

O que Arendt percebe como atenção ao particular e o que Adorno qualifica como promessa são outros nomes para isso que em Benjamin denominamos materialismo e metafísica. Esse par também acompanha a teoria e a metodologia do filósofo diante das obras literárias; e, evidentemente, assim Benjamin procede em suas análises de poemas. Nesse sentido, a sua atenção ao particular parece suscitar um esforço filológico bastante peculiar, com um senso aguçado para os detalhes estranhos ou absurdos das obras que foram objetos de sua crítica. É o que fundamenta no filósofo a apreensão bastante particular que faz da monadologia de Leibniz - que na sua obra aparece como epistemologia que une o particular (o detalhe, o fragmento, o único) e o universal (o semelhante, a ideia, a história), de modo que já não se poderia falar de uma separação dessas duas esferas. No particular, o universal.

Em Origem do drama barroco alemão ${ }^{10}$ Benjamin toma de empréstimo a imagem do mundo como mônada para descrever o mundo das ideias. Em outras palavras, realiza uma secularização da monadologia e uma conversão de seu estatuto ontológico em uma epistemologia - isto é, como descrição das condiçôes de possibilidade do conhecimento. $\mathrm{O}$ alcance de uma tal conversão pode ser medido em comparação com a sua formulação ontológica em Leibniz. A monadologia é acompanhada em sua obra por uma teoria dos mundos possíveis.

Para o inventor do cálculo infinitesimal, Deus teria concebido o melhor mundo entre os possíveis. A vida e as coisas, tal como existem, são objeto da

${ }^{17}$ ARENDT, Hannah. Homens em tempos sombrios. Lisboa: Relógio D’Água, 199I, p. 190.

${ }^{18}$ ADORNO, Theodor W. “Caracterização de Walter Benjamin”. In: Prismas. Trad. Augustin Wernet e Jorge Mattos Brito de Almeida. São Paulo: Editora Ática, 1998, p. 225.

${ }^{19}$ Mais especificamente, no Prefácio Epistemo-Crítico. Cf. BENJAMIN, Walter. Origem do drama trágico alemão. Trad. João Barrento. Belo Horizonte: Autêntica, 2oII, p. 35-37. A expressão Trauerspiel é traduzida por João Barrento como "drama trágico"; optei, no entanto, por permanecer, no corpo do texto, com a opção de Sergio Rouanet, "drama barroco". 
vontade divina, que por decisão cria este mundo e não outros. Do ponto de vista da Teodiceia ${ }^{20}$ Deus cria este mundo porque é onisciente - e conhece todos os outros mundos que ele próprio poderia ter criado - e porque é onipotente - tendo, portanto, o poder necessário para criar qualquer mundo que pudesse ser concebido por Sua razão; e não seria bom nem justo se não optasse, se não decidisse, por meio de um juízo, pelo melhor mundo possível. Com efeito, as mônadas também são criadas em sua perfeição ${ }^{2 n}$ Essa perfeição inclui todos os momentos imperfeitos dos universos que poderiam ter sido e não foram.

A secularização da monadologia em Benjamin suspende a necessidade da perfeição do que existe, deslocando-a para um plano ideal por vir. As coisas em si não são perfeitas. Pelo contrário, aguardam aperfeiçoamento. É nesse sentido que toda a teoria de Benjamin se faz entre dois polos: a constatação do ocorrido e a sua possibilidade de salvação na recuperação das formas daquilo que poderia ter ocorrido. ${ }^{22} \mathrm{Na}$ sua filosofia da história, por exemplo, o historiador não tem a tarefa de descrever somente os fatos "como eles de fato teriam ocorrido", como também a de descrevê-los do ponto de vista daquilo que poderia ter acontecido - o que Benjamin chama de "escovar a história a contrapelo" ${ }^{23}$ No lugar de Deus, entra em cena a ação humana aperfeiçoadora: do materialista histórico (historiador e revolucionário), que aperfeiçoa a história ("Sobre o conceito de história”); do tradutor, que aperfeiçoa as línguas (“A tarefa do tradutor”): ${ }^{24}$ do filósofo, que salva os fenômenos (Origem do drama barroco alemão); etc.

${ }^{20}$ LEIBNIZ, G. W. Ensaios de Teodiceia. Trad. William de Siqueira Piauí e Juliana Cecci Silva. São Paulo: Estação Liberdade, 2013.

${ }^{21}$ Cf. também DANOWSKI, Deborah. "Leibniz e as voltas do tempo". In: Dois pontos, v. 2, n. I, Curitiba, São Carlos, out., 2005, p. IOI-I22.

${ }^{22}$ Desenvolvo essa chave de compreensão da obra de Benjamin em FERNANDES, Rafael Zacca. As flores da poesia na terra do saber: uma teoria do poema em Walter Benjamin. Tese (Doutorado em Filosofia). Departamento de Filosofia. Pontifícia Universidade Católica do Rio de Janeiro. Rio de Janeiro, 20I9.

23 "Nunca houve um monumento da cultura que não fosse também um monumento da barbárie. E, assim como a cultura não é isenta de barbárie, não o é, tampouco, o processo de transmissão da cultura. Por isso, na medida do possível, o materialista histórico se desvia dela. Considera a sua tarefa escovar a história a contrapelo.” BENJAMIN, Walter, 1994, p. 225.

${ }^{24}$ BENJAMIN, Walter. "A tarefa do tradutor” Trad. Susana Kampff Lages. In: Escritos sobre mito e linguagem. São Paulo: Duas Cidades; Ed. 34, 20 II. 
O poema é mônada, e isso tem dois sentidos para as relações entre poesia e história. A primeira, já adivinhamos: o poema é um condensado da história, que não deve ser explicado a partir da exposição dos fenômenos históricos, mas que encontra na sua própria explicação uma tal exposição. Não se compreende a Paris do Segundo Império de Napoleão III para, em função dessa totalidade histórica, criar condições de leitura de um poema de Baudelaire (como na teoria do reflexo de parte do marxismo ortodoxo, que vê nos fenômenos superestruturais uma identidade com os processos que ocorrem na base econômica) ${ }^{25} \mathrm{~A}$ bem da verdade, ocorre o contrário: na filosofia e na prática de Walter Benjamin como crítico de poesia, os poemas se tornam fonte privilegiada de acesso a uma verdade histórica.

O poema é, ele próprio, uma condensação daquilo que Benjamin chamaria nos seus fragmentos "Sobre o conceito de história" de tempo-de-agora, de Jetztzeit. Não ocorre que ele possa ser explicado pelos processos históricos mais amplos, sendo deles deduzidos; a história se encontra nele. No poema vive a sua pré e pós-história: tanto do ponto de vista do que de fato ocorreu quanto de outro ponto de vista, o da salvação, do que poderia ter ocorrido.

\section{O poema é mônada: os poemas no poema}

O poema é mônada: o segundo sentido que gostaria de examinar nesse enunciado carrega outra possibilidade para a compreensão da relação entre poesia e história em Walter Benjamin.

Para ter acesso a essa outra relação, precisamos dar um passo atrás, e retornar a um texto de Benjamin da juventude, escrito em 19I4, sobre "Dois poemas de Friedrich Hölderlin". A ocasião em que o texto foi escrito e as conclusões a que chega o filósofo sobre os poemas do poeta não poderão ser desdobradas agora. Por isso, gostaria de concentrar a atenção nos primeiros parágrafos desse texto,

${ }^{25}$ Por exemplo, em Georg Lukács, para quem, segundo o seu prefácio à edição húngara de Arte e sociedade, "toda categoria artística, inclusive a mais abstrata, nasce das necessidades mais profundas da vida humana, determina suas formas de realização positiva e negativa e é por elas determinada. É por isto que a estética tem como seu centro o reflexo artístico da realidade." LUKÁCS, Georg. Arte e sociedade. Trad. Carlos Nelson Coutinho e José Paulo Netto. Rio de Janeiro: Editora da UFRJ, 20II, p. 34. 
em que se verificam considerações metodológicas preliminares de Benjamin (um procedimento usual em diversas de suas críticas: cada crítica contém - usualmente em seus primeiros parágrafos - um pequeno prefácio que elabora uma espécie de crítica da crítica, de filosofia da crítica.)

O filósofo nos adverte que irá investigar dois poemas, "Coragem de poeta" [Dichtermut] e "Timidez" [Blödigkeit], que são, na verdade, duas versóes de um mesmo texto poético de Hölderlin. Nesses parágrafos, Benjamin tenta compreender como se podem comparar dois textos poéticos que tentam realizar a mesma coisa. É então que estabelece que esses poemas só podem ser comparados em função de um elemento que lhes é comum. Esse elemento não aflora à superfície, não aparece no poema. Só pode ser deduzido da atividade crítica. É o seu "poetificado".

Deve-se comparar o "poetificado" de ambas as versóes - não em sua igualdade, que não existe, mas em sua "comparabilidade". Os dois poemas estão ligados em seu "poetificado" e, a saber, por uma atitude para com o mundo. Esta atitude é a coragem, a qual, quanto mais profundamente é compreendida, torna-se menos uma característica do que uma relação do homem com o mundo e do mundo com o homem.26

O "poetificado", ou das Gedichtete, é um conjunto de forças, ou relações vitais, que o trabalho do poema retira da vida e reconfigura em seu interior. Se voltarmos aos poemas de Baudelaire, poderíamos dizer que o que é poetificado em "Ao leitor" é um conjunto de forças históricas no Segundo Império de Napoleão III que se reconfiguram e ganham outra aparência no poema. Essa reoperação dos elementos, visando, na linguagem, a reconfigurar o sentido e o sem-sentido do que existe, ao mesmo tempo transforma e conserva a história. E o faz, segundo Benjamin, porque tenta responder a uma tarefa.

Existiria, portanto, uma tarefa do poema. No caso de "Ao leitor", uma tarefa de desnudamento da nova experiência que toda a geração recalca. Nos poemas

${ }^{26}$ BENJAMIN, Walter. "Dois poemas de Friedrich Hölderlin” Trad. Susana Kampff Lages e Ernani Chaves. 20II, p. 43. 
que Benjamin analisa no ensaio de 19I4, aqueles de Hölderlin, a tarefa coincide com uma apresentação da coragem em um mundo saturado de perigos.

O que permite a comparação entre as duas versões de um mesmo poema é o conceito de poetificado, porque ele revela que os poemas respondem, como diferentes soluções, a uma mesma tarefa. Essa tarefa é o elemento de comparação, propriamente dito, que permite o cotejamento não dos poemas em si, mas daquilo que eles poetificaram.

Desse ponto de vista, mais importante que o poema é o que no poema resiste como possibilidade de sua confecção. O conceito de tarefa opera na legibilidade do poema um efeito monadológico: o poema é mônada e contém, em seu interior, um complexo que serve de apoio para diversas operações básicas que podem refazêlo em outras formas. É o que defendi, em minha tese de doutorado, As flores da poesia na terra do saber: uma teoria do poema em Walter Benjamin: existe em Benjamin uma região não imediatamente acessível nos poemas, que pode ser nomeada com o conceito de "inconsciente poético" ${ }^{27}$

O inconsciente poético nada tem a ver com o inconsciente do sujeito que cria as obras. Não significa, portanto, que nas obras haja certos motivos psicológicos de seu autor. Não é a vida do poeta que se inscreve nas obras. E, desse ponto de vista, são as obras mesmas que possuem um inconsciente, que não é "poético" por ser "belo" ou qualquer coisa que o valha; é "poético" porque guarda, em seu interior, mecanismos, sistemas, configurações e determinações que condicionam a manifestação poética mesma na forma de um saber, ou de um pensamento. A própria ideia de um poetificado nos poemas de Hölderlin diz respeito à descoberta desses "mecanismos reflexivos": os poemas "Coragem de poeta" e "Timidez" podem ser concebidos como manifestaçôes poéticas de mecanismos postos em movimentação pela própria ação do poetificado.

Desse ponto de vista, um poema escrito é um sintoma de si mesmo. Um sintoma de seu próprio inconsciente poético. A crítica, a tradução, uma segunda versão: em todos esses casos, podemos conceber que esses trabalhos, essas elaborações, recolocam o inconsciente em uma nova manifestação.

Dizer um inconsciente do poema em Benjamin significa dizer, por analogia ao inconsciente pulsional, que existem cadeias de pensamento que sobrevivem

${ }^{27}$ FERNANDES, Rafael Zacca. Op. cit., p. 53-65. 
inconscientemente nos poemas ${ }^{28}$ Não cadeias de pensamento do sujeito, mas dos próprios poemas. Como se a aparência legível do poema fosse a sua própria consciência, condicionada por essas cadeias invisíveis a olho nu. Essa forma de colocar as coisas desprende a noção de inconsciente de sua fundação exclusiva na psicanálise. Podemos formulá-la muito além do inconsciente pulsional.

Chamemos de inconsciente, então, uma estruturação qualquer de acontecimentos sobre os quais um pensamento a posteriori pode descobrir a ação de forças razoavelmente "lógicas" (dotadas de uma logicidade interna que não precisa encontrar identidade com um mundo lógico "geral”) que não se apresentam à consciência do(s) agente(s) envolvido(s), mas que se tornam invariavelmente reconhecidas, pelo pensamento que por ventura as descubra, como um a priori dos eventos.

A ideia de que um poema "pensa" poderia levar a crer que todo poema tem um elemento qualquer conceitual, seja explicitamente, seja em suas entrelinhas. Não é isso que se propõe aqui. Um poema, de caráter conceitual ou não, traz em sua forma interna cadeias de pensamento. Mesmo um poema didático, dotado de um discurso coeso e lógico, tem, em seu interior, cadeias de pensamento e logicidades de que ele próprio não pode se dar conta. Nesse sentido, a crítica é o momento em que o inconsciente das obras vem à consciência em uma nova forma textual.

O inconsciente é uma estrutura descoberta necessariamente a posteriori e que se insere como elemento de legibilidade de um fenômeno como um a priori. Ele funda a possibilidade de desdobramento dos poemas. Esse desdobramento se traduz em pelo menos três atitudes básicas na filosofia de Benjamin. As obras

${ }^{28}$ Estabeleci essa analogia em minha tese da seguinte forma: "Com o conceito de poetificado, abre-se para Benjamin uma região do poema que, de outra forma, dificilmente se deixaria penetrar pelo pensamento. O seu estabelecimento permite um avanço da teoria sobre os territórios tomados como inexplicáveis por sua qualidade um tanto quanto etérea. O que Benjamin descobre é um inconsciente poético na medida em que o próprio poema é tratado como uma espécie de sintoma, como a persistência de impressóes deixadas pela tarefa poética, que, apesar de não nomeada francamente, se deixa ver mediante o trabalho da crítica. (...) o poema se torna um lugar privilegiado para o pensamento, lá onde poderia ser o simples objeto de uma fruição ou de uma pesquisa puramente técnica. Mais do que isso, o objeto se torna desde aí um medium-de-reflexão, mesmo anos antes da conclusão de sua tese sobre o romantismo alemão, em que usará esse termo para definir a qualidade do meio em que repousam as obras para os românticos.” Ibid., p. 6I-63. 
possuem um índice de "criticabilidade" (que autoriza, e mesmo contém, a crítica): a crítica é desdobrada do interior do poema ${ }^{29}$ Outro de "traduzibilidade" (que autoriza e contém a tradução): o original, como afirma Benjamin em "A tarefa do tradutor", contém as suas traduçôes. E outro de "refazibilidade" (que autoriza e contém outras versões de uma mesma composição).

O poema é mônada: nele, vivem suas críticas possíveis, as traduções que ainda pode receber e, por fim, todos os poemas que poderiam ter sido escritos.

Isso significa reconhecer na poesia uma seriedade histórica: ela apresenta uma solução para uma tarefa histórica, como também revela que essa tarefa existe e pode ser resolvida de outras maneiras. Melhor: a poesia exige a sua solução de diferentes maneiras. Porque, diferentemente da monadologia de Leibniz, que concebia o mundo como o mais perfeito entre os possíveis, o projeto filosófico de Benjamin, mesmo quando se debruça sobre poemas, dedica-se a retomar "a fraca força messiânica" que se reservou a cada geração ${ }^{30}$

\section{Referências}

ADORNO, Theodor W. Prismas. Trad. Augustin Wernet e Jorge Mattos Brito de Almeida. São Paulo: Editora Ática, 1998.

ARENDT, Hannah. Homens em tempos sombrios. Lisboa: Relógio D’Água, 1991. BENJAMIN, Walter. Charles Baudelaire, um lírico no auge do capitalismo. Obras escolhidas. V. 3. Trad. José Carlos Martins Barbosa; Hemerson Alves Batista. São Paulo: Brasiliense, 1989.

. Escritos sobre mito e linguagem. São Paulo: Duas Cidades; ed. 34,

2OII.

. Magia e técnica, arte e politica. Obras escolhidas. V. I. Trad. Sergio Paulo Rouanet. São Paulo: Brasiliense, 1987.

. O anjo da história. Trad. João Barrento. Belo Horizonte: Autêntica Editora, 2oI2.

${ }^{29}$ Isso foi estabelecido, de certa forma, na tese de doutorado de Benjamin, O conceito de critica de arte no primeiro romantismo alemão. Trad. Márcio Seligmann-Silva. São Paulo: Iluminuras, 2 OII.

30 BENJAMIN, Walter, 1994, p. 223. 
- O conceito de crítica de arte no romantismo alemão. Trad. Márcio Seligmann-Silva. São Paulo: Iluminuras, 20 II.

. Origem do drama trágico alemão. Trad. João Barrento. Belo

Horizonte: Autêntica, 201 .

. Passagens. Trad. Irene Aron e Cleonice Paes Barreto Mourão. Belo

Horizonte: Editora UFMG, 2009.

BAUDELAIRE, Charles. Poesia e prosa. Volume único. Rio de Janeiro: Nova Aguilar, 1995.

. "Les Fleurs du Mal". In: Euvres complètes. Paris: Gallimard, I975.

BUCK-MORSS, Susan. "Estética e anestética: o ensaio sobre a obra de arte de Walter Benjamin”. Trad. Rafael Lopes Azize. In: Travessia: revista de literatura, n. 33. Florianópolis: EdUFSC, ago.-dez. 1996. p. II-4I.

CRARY, Jonathan. Técnicas do observador. Trad. Verrah Chamma. Rio de Janeiro: Contraponto, 2012.

DANOWSKI, Deborah. "Leibniz e as voltas do tempo". In: Dois pontos, v. 2, n. I, Curitiba, São Carlos, out., 2005. p. IOI-I22.

FERNANDES, Rafael Zacca. As flores da poesia na terra do saber: uma teoria do poema em Walter Benjamin. Tese (Doutorado em Filosofia). Departamento de Filosofia. Pontifícia Universidade Católica do Rio de Janeiro. Rio de Janeiro, 2019 .

LEIBNIZ, Gottfried Wilhelm. A monadologia; Discurso de metafísica e outros textos. Trad. Carlos Lopes de Mattos. São Paulo: Abril Cultural, 1979. . Ensaios de Teodiceia. Trad. William de Siqueira Piauí e Juliana Cecci Silva. São Paulo: Estação Liberdade, 2or3.

LUKÁCS, Georg. Arte e Sociedade. Trad. Carlos Nelson Coutinho e José Paulo Netto. Rio de Janeiro: Editora da UFRJ, 20II.

Resumo: O presente artigo pretende fornecer uma leitura de dois conceitos que estão em textos da juventude e da maturidade de Walter Benjamin e que permitem estabelecer uma relação produtiva de análise de poemas e de pe-
Abstract: This article aims to provide an interpretation of two concepts from Walter Benjamin's youth and maturity texts which allow for the establishment of a productive relation of analysis concerning both poems and 
ríodos históricos, a saber: o de "poeti- historical periods: the concept of "poficado" [das Gedichtete], tal como apa- etized" [das Gedichtete], as it appears rece no texto sobre Friedrich Hölderlin, in the text about Friedrich Hölderlin na primeira metade da década de I9ro; e in the first half of the roro decade; and o de "mônada", segundo a sua reformu- the concept of "monad", in accordance lação na fase materialista, contemporâ- with its reformulation in the materianeo à escrita do ensaio sobre Charles list phase, contemporary to the writing Baudelaire, no final da década de 1930. of the essay on Charles Baudelaire, in A hipótese sustentada aqui é que a legi- the end of the decade of 1930. My hybilidade de uma continuidade entre os dois conceitos é possível a partir de um terceiro conceito, não descrito pelo próprio Benjamin, mas dedutível de seu trabalho, que poderíamos nomear como "inconsciente poético"..

Palavras-chave: Walter Benjamin; Charles Baudelaire; Filosofia da história; Filosofia da arte; Modernidade. pothesis is that it is possible to read a continuity between the two concepts through a third one, which was not described by Benjamin himself but could be deduced from his own work, and that we could name the "poetic unconscious”.

KeYwords: Walter Benjamin; Charles Baudelaire; Philosophy of History; Philosophy of Art; Modernity. 